\title{
Mutations in ZIC2 in human holoprosencephaly: description of a Novel ZIC2 specific phenotype and comprehensive analysis of 157 individuals
}

\author{
Benjamin D Solomon, ${ }^{1}$ Felicitas Lacbawan, ${ }^{1,2}$ Sandra Mercier, ${ }^{3,4}$ Nancy J Clegg, ${ }^{5}$ \\ Mauricio R Delgado, ${ }^{5}$ Kenneth Rosenbaum, ${ }^{6}$ Christèle Dubourg, ${ }^{3}$ Veronique David, ${ }^{3}$ \\ Ann Haskins Olney, ${ }^{7}$ Lars-Erik Wehner, ${ }^{8}$ Ute Hehr, ${ }^{9}$ Sherri Bale, ${ }^{10}$ Aimee Paulussen, ${ }^{11}$ \\ Hubert J Smeets, ${ }^{11,12}$ Emily Hardisty, ${ }^{13}$ Anna Tylki-Szymanska, ${ }^{14}$ Ewa Pronicka, ${ }^{14}$ \\ Michelle Clemens, ${ }^{15}$ Elizabeth McPherson, ${ }^{16}$ Raoul C M Hennekam, ${ }^{17,18}$ Jin Hahn, ${ }^{19}$ \\ Elaine Stashinko, ${ }^{20}$ Eric Levey ${ }_{2}^{20}$ Dagmar Wieczorek, ${ }^{21}$ Elizabeth Roeder, ${ }^{22}$ \\ Chayim Can Schell-Apacik, ${ }^{23,24}$ Carol W Booth, ${ }^{25}$ Ronald L Thomas, ${ }^{26}$ \\ Sue Kenwrick, ${ }^{27}$ Derek A T Cummings, ${ }^{28}$ Sophia M Bous, ${ }^{1}$ Amelia Keaton, ${ }^{1}$ \\ Joan Z Balog, ${ }^{1}$ Donald Hadley, ${ }^{1}$ Nan Zhou, ${ }^{1}$ Robert Long, ${ }^{1}$ Jorge I Vélez, \\ Daniel E Pineda-Alvarez, ${ }^{1}$ Sylvie Odent, ${ }^{3,4}$ Erich Roessler, $^{1}$ Maximilian Muenke ${ }^{1}$
}

For numbered affiliations see end of article.

\section{Correspondence to Maximilian Muenke, National Institutes of Health, Building 35, Room 1B-203, Bethesda, MD 20892, USA; \\ mamuenke@mail.nih.gov}

BDS and FL authors contributed equally.

Received 7 September 2009 Revised 22 November 2009 Accepted 24 November 2009 Published Online First

2 December 2009

\section{ABSTRACT}

Background Holoprosencephaly (HPE), the most common malformation of the human forebrain, may be due to mutations in genes associated with non-syndromic HPE. Mutations in ZIC2, located on chromosome $13 \mathrm{q} 32$, are a common cause of non-syndromic, non-chromosomal HPE.

Objective To characterise genetic and clinical findings in patients with ZIC2 mutations.

Methods Through the National Institutes of Health and collaborating centres, DNA from approximately 1200 individuals with HPE spectrum disorders was analysed for sequence variations in ZIC2. Clinical details were examined and all other known cases of mutations in ZIC2 were included through a literature search.

Results By direct sequencing of DNA samples of an unselected group of unrelated patients with HPE in our $\mathrm{NIH}$ laboratory, ZIC2 mutations were found in $8.4 \%$ (49/ 582) of probands. A total of 157 individuals from 119 unrelated kindreds are described, including 141 patients with intragenic sequence determined mutations in ZIC2. Only 39/157 patients have previously been clinically described. Unlike HPE due to mutations in other genes, most mutations occur de novo and the distribution of HPE types differs significantly from that of non-ZIC2 related HPE. Evidence is presented for the presence of a novel facial phenotype which includes bitemporal narrowing, upslanting palpebral fissures, a short nose with anteverted nares, a broad and well demarcated philtrum, and large ears.

Conclusions HPE due to ZIC2 mutations is distinct from that due to mutations in other genes. This may shed light on the mechanisms involved in formation of the forebrain and face and will help direct genetic counselling and diagnostic strategies.

\section{INTRODUCTION}

Holoprosencephaly (HPE) is the most common malformation of the human forebrain, and results from failed or incomplete forebrain cleavage early in gestation. HPE occurs in 1 in 250 gestations, though the vast majority of conceptions with HPE do not survive to birth. ${ }^{1}{ }^{2} \mathrm{HPE}$ is categorised by the degree of forebrain separation into alobar, semilobar, and lobar types, from most to least severe. More recently, middle interhemispheric variant (MIHV) HPE has also been described, which includes failed separation of only the posterior frontal and parietal lobes. ${ }^{3-6}$ The distribution of HPE types in both living patients and deceased fetuses with non-chromosomal, non-syndromic HPE has been estimated to be $10-40 \%$ alobar, $43-45 \%$ semilobar, and 17-33\% lobar HPE (Muenke Lab, unpublished data, 2010). 78

Common clinical features among patients with HPE include neurological impairment (often severe), seizures, diabetes insipidus, and characteristic dysmorphic facies. Traditionally, it is thought that in HPE 'the face predicts the brain': in other words, more severe craniofacial anomalies correlate with more severe neuroanatomic findings. ${ }^{4}$ At the most severe end of the spectrum, facial features in patients with alobar HPE may include cyclopia and a proboscis (a tubular nasal structure located above the fused eyes). Other, more common facial dysmorphisms in less severely affected patients include microcephaly (though hydrocephalus can lead to macrocephaly), hypotelorism, a flat nasal bridge, and cleft lip and/or palate. At the least severe end of the spectrum, termed microform HPE, patients may have subtle features such as mild microcephaly, hypotelorism, and a single maxillary central incisor (SMCI) without appreciable central nervous system (CNS) anomalies on conventional neuroimaging. These individuals are often identified due to the presence of a severely affected relative. ${ }^{6910}$

HPE is aetiologically heterogeneous, and may be caused by cytogenetic anomalies, teratogenic influences, occur in the context of a syndrome, or be due to mutations in one of over $10 \mathrm{HPE}$ associated genes. $^{6} 7911-13$ In patients with HPE who have a normal chromosome analysis, a typical 
initial diagnostic strategy is to screen for mutations in four genes: SHH (MIM 600725), ZIC2 (MIM 603073), SIX3 (MIM 603714), and TGIF (MIM 602630). Mutations in these genes can arise de novo or may be found in multiple members of large families segregating HPE spectrum anomalies. In large kindreds, family studies demonstrate the incomplete penetrance and highly variable expressivity of these mutations. ${ }^{3} 4614$

ZIC2, located at chromosome 13q32, was first identified as an HPE candidate gene due to individuals with brain anomalies who were found to have deletions involving the long arm of chromosome 13. Subsequent analyses of patients with HPE identified mutations in ZIC2. ${ }^{15-17}$ ZIC2 mutations have been thought to be the second most common identified cause of non-chromosomal non-syndromic HPE (after mutations in $S H H)$. In recent estimates, at least $3 \%$ of probands with HPE have mutations in ZIC2, though a more accurate estimate is likely to be at least double that. ${ }^{6} 18$

ZIC2 encodes a transcription factor that plays several roles in neurological development. Early in development, ZIC2 is predicted to play a role in axial midline establishment; later, ZIC2 appears to affect the development of the dorsal telencephalon. ${ }^{19} 20$ This latter role may explain the occurrence of neural tube defects in individuals with mutations in ZIC2, as well as the presence of MIHV type HPE, though this type can be seen in HPE due to mutations in other genes as well. ${ }^{21}$ Mouse models show that complete absence of Zic2 activity results in HPE due to mid gastrulation failure of axial midline development, homozygous hypomorphic alleles result in normal gastrulation but dorsal forebrain malformations at later stages, and heterozygotes for null alleles are phenotypically normal. However, features in homozygous null mice recapitulate the entire spectrum of HPE severity, suggesting that the phenotypic consequences of mutations depend on the perturbed developmental stage and may be affected by interacting genes. ${ }^{18} 202223$ Of note, it has been suggested that mutations in ZIC2 may cause HPE brain findings, but often do not result in facial features typical of HPE due to mutations in other genes-in other words, the face would not 'predict the brain'. ${ }^{17} 24$

Here we present clinical and genetic data on all known individuals with mutations in ZIC2, approximately half of whom were identified through our laboratory at the National Institutes of Health (NIH), and over three quarters of whom have not been previously clinically described. We also present data on individuals with deletions of the ZIC2 locus ascertained by multiplex ligation dependent probe amplification (MLPA) and fluorescence in situ hybridisation (FISH), chromosome analysis, or by oligonucleotide array comparative genomic hybridisation (aCGH). Through this comprehensive evaluation, we can identify specific characteristics of these individuals that can differentiate patients with HPE due to ZIC2 mutations from patients with HPE due to other genetic causes.

\section{METHODS \\ Patient recruitment, mutation screening, and clinical assessments}

Blood samples from approximately 600 individuals with HPE spectrum disorders and their relatives were collected over 18 years in our laboratory at the NIH. These samples were analysed for potential sequence variations in the ZIC2 gene under our National Human Genome Research Institute/NIH Institutional Review Board (IRB) approved brain research protocol (with appropriate consent). A strategy for screening the ZIC2 gene has previously been described. ${ }^{18}$
Approximately 600 additional probands with HPE were screened through collaborating centres, for a total of approximately 1200 probands with HPE spectrum anomalies. This total cohort includes deceased fetuses (of note, the approximately 600 patients included in the NIH cohort does not include deceased fetuses), live born infants, and currently living patients. After mutation was identified in a proband, additional individuals were identified through testing of relatives. The analysis of clinical characteristics was performed retrospectively; the quality of available clinical information was highly variable.

In terms of $\mathrm{NIH}$ patients, before 2006, referring clinicians (which include geneticists, neurologists, obstetricians, and pathologists) were asked to send samples with available clinical data, including clinical summaries, photos, and neuroimaging. Starting in 2006, referring clinicians additionally filled out a standardised, brief clinical checklist describing clinical findings, family history, and risk factors. In the process of reviewing information for this analysis, many referring clinicians were recontacted in order to request additional data. Four patients were seen at the NIH for a comprehensive evaluation.

In terms of patients who were not part of the NIH cohort, information was obtained through collaborators who sent de-identified clinical and laboratory data: Laboratoire de Génétique Moléculaire (Rennes, France); Center for and Department of Human Genetics (Regensburg, Germany); GeneDx (Gaithersburg, Maryland, USA); Maastricht University Medical Centre (Maastricht, The Netherlands). Collaborating centres shared (with appropriate consent) available clinical data, typically in the form of a narrative summary, photos and neuroimaging results.

All patients on whom craniofacial data are presented were assessed in person by clinical dysmorphologists. Thirty probands had photos available for review, while detailed physical examination assessments performed by clinical dysmorphologist were available for 29 additional probands. All HPE types were identified by neuroimaging, performed by ultrasound (in the majority of fetal cases), CT, MRI, or by pathological study. MRI was available in approximately half of cases with identified HPE type, with a bias for more recently ascertained cases.

\section{Literature review of reported cases of holoprosencephaly spectrum disorders due to mutations in ZIC2}

A Medline search was conducted to find previously reported cases of holoprosencephaly due to mutations in ZIC2. The key words and search terms included 'ZIC2', 'holoprosencephaly', 'HPE', '13q', and '13q32'. References were also obtained from articles found through the literature search. As loci near ZIC2 may contribute to brain malformations and there have been numerous reported cases of deletions of $13 q$ with unreported clinical and genetic characterisations, only cases with clear HPE and definitive deletion of the ZIC2 locus without involvement of other chromosomes were considered. Cases were used from the following papers and abstracts: Brown et al, 1993, Brown et al, 1995, Brown et al, 1998; Chen et al, 1998; Nanni et al, 1999. Gutierrez et al, 2001; Orioli et al, 2001; Brown et al, 2001; Marcorelles et al, 2002; Dubourg et al, 2004; Brown et al, 2005; Júnior et al, 2006; Paulussen et al, 2008, Eur Soc of Hum Genet, abstract; Roessler et al, 2009; Quélin et al, 2009. ${ }^{15-18 ~ 24-34}$

\section{Statistical analysis}

In the descriptions below, unless otherwise stated, results refer only to individuals with intragenic sequence determined mutations in ZIC2, not patients with large genomic imbalances. Patients with large genomic imbalances were not included in 
most statistical analyses due to the relatively low numbers and because the testing method differed among patients (including traditional cytogenetic analysis, FISH testing, and aCGH), potentially invalidating comparisons.

Denominators differ among findings, as the prevalence of each phenotypic manifestation was calculated only where data were available for that specific finding (table 1$). \chi^{2}$ and Fisher's exact tests were used to determine statistical differences between patient groups.

\section{RESULTS \\ Patients}

We describe a total of 157 patients, including 141 patients from 103 unrelated kindreds with sequence determined mutations in ZIC2, seven patients with deletions of ZIC2 ascertained by FISH testing or MLPA, and nine patients with deletions of ZIC2 ascertained by chromosome analysis or by oligonucleotide aCGH. While the majority of these mutations have been reported, only $25 \%$ (39/157) have previously been clinically described. Of the 157 patients, 77 patients were identified at the $\mathrm{NIH}, 72$ were identified through collaborating centres, and eight patients were identified through a literature search (all eight of whom were patients with deletions of the ZIC2 locus as part of a larger genetic imbalance). ${ }^{15-17} 24-34$

By direct sequencing of DNA samples of an unselected group of unrelated patients with HPE in our laboratory at the NIH, $8.4 \%(49 / 582)$ have mutations in ZIC2. Additional cases were initially ascertained through screening methodology, including screening methods involving single strand conformational polymorphism (SSCP) analysis and denaturing high performance liquid chromatography (dHPLC). Multiple international testing centres additionally contributed cases as described above (Methods). A summary of all patients is presented in table 2 .

\section{Inheritance}

Among probands in whom parents were available for testing (65/103 families), mutations were found to be de novo in $72 \%$, maternally inherited in 18\%, and paternally inherited in $9 \%$ of patients. There were no kindreds in which mutations or affected individuals were identified in more than two generations. However, in five cases, pedigree analysis showed that a mutation appeared to be inherited from a parent who had multiple affected children but for whom mutation testing was negative, implying either allele dropout or, more likely, germline mosaicism.

\section{HPE type}

Prevalences of HPE types are presented in table 3. Examples of characteristic findings on neuroimaging are shown in figure 1.

Table 1 Denominators used to calculate prevalence of findings in individuals with intragenic sequence determined mutations in ZIC2

\begin{tabular}{lcc}
\hline & Probands & $\begin{array}{c}\text { All affected } \\
\text { individuals* }\end{array}$ \\
\hline Total patients & 103 & 141 \\
Gender & 90 & 127 \\
Holoprosencephaly (HPE) type & 86 & 105 \\
Structural neurological findings $\dagger$ & 81 & 92 \\
Inheritance & 65 & 85 \\
Extra-neurological findings & 64 & 76 \\
Facial phenotype $\ddagger$ & 59 & 59
\end{tabular}

*Including probands and relatives.

†In addition to HPE.

$\ddagger 30$ photos, 29 full facial descriptions.
For patients with intragenic sequence determined mutations, the distribution of HPE types is not equal, with alobar and semilobar HPE significantly overrepresented $\quad\left(\chi_{(2)}^{2}=23.65\right.$, $p<0.0001)$. MIHV was not included in the analysis due to paucity of cases. Due to the relatively few cases, the group of patients with larger genomic imbalances, including deletion of ZIC2, was not analysed.

We compared the distribution of HPE types in patients with intragenic sequence determined mutations in ZIC2 to two previous studies describing the prevalence of the major HPE types, as well as to a group of HPE probands ascertained from samples sent to the NIH for clinical testing in an approximately 3 year period after the establishment of a reference laboratory (table 4). ${ }^{7}$ The groups described by Lazaro et al (2004) and the $\mathrm{NIH}$ groups are likely most similar to our cohort by the fact that all three groups had non-chromosomal, non-syndromic HPE. ${ }^{7}$ The cohort described by Orioli et al (2007), on the other hand, may include some patients with chromosomal anomalies, and also included only patients who survived to birth. ${ }^{8}$ There was a significantly different distribution of HPE types in our cohort of patients with intragenic ZIC2 mutations versus those described by Lazaro et al (2004) and ascertained through our general NIH HPE cohort. ${ }^{7}$ There was not a statistically significant difference compared to the Orioli et al (2007) group, though this latter cohort does not appear well matched with our ZIC2 cohort. $^{8}$

\section{Clinical features}

Among all individuals with mutations (including both probands and relatives of probands) for whom gender was known, 50\% were female and $50 \%$ were male. Among probands for whom gender was known, 51\% were female and 49\% were male.

Patients with recognisable brain anomalies invariably had some degree of neurological impairment. Of 65 families tested, 18 parents were identified as having mutations initially found in their severely affected children; of the eight parents who had mutations (not germline mutations) who were fully examined, only two parents were not found to have mild features of microform HPE. The overall penetrance of phenotypic manifestations (including alobar, semilobar, lobar, MIHV, and microform HPE, as well as HPE of unknown type) due to intragenic mutations in ZIC2 is estimated to be 93\%; the prevalence of structural brain anomalies consistent with a diagnosis of frank HPE (by conventional neuroimaging or pathology) is estimated to be $88 \%$ of patients with intragenic mutations.

Among 59 patients for whom information was available, at least 67\% (40/59) did not display typical HPE facial features such as the combination of hypotelorism, midface hypoplasia with flat nasal bridge, cleft lip/palate, and SMCI, features frequently seen in patients with mutations in genes such as SHH and SIX3. ${ }^{21}$ While $33 \%$ of patients (19/59) were reported as having facial characteristics commonly described in HPE (as above), none of these latter patients had photographs available for review, and were only described in clinical summaries provided by referring clinicians. In other words, none of the 30 available photos show facial features in which patients with mutations in ZIC2 have typical HPE craniofacial manifestations, but some clinicians describe more typical HPE facial features in written summaries. Additionally, no patients had facial findings at the most severe end of the spectrum, such as cyclopia, synophthalmia, or a proboscis. As anthropometric measurements were not uniformly available, detailed calculations as to the prevalence of certain features were not attempted. 
Table 2 All known patients with mutations affecting ZIC2

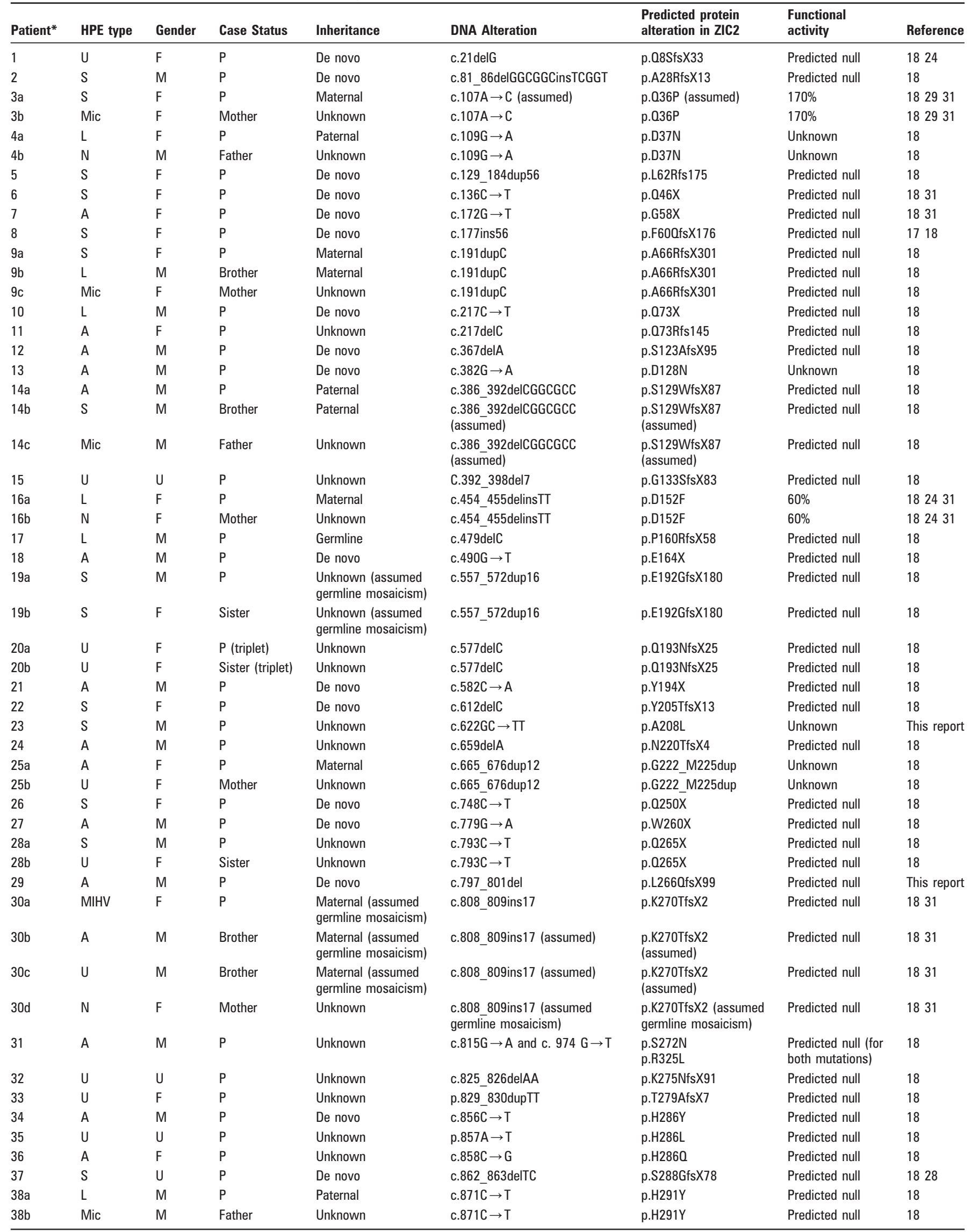


Table 2 Continued

\begin{tabular}{|c|c|c|c|c|c|c|c|c|}
\hline Patient* & HPE type & Gender & Case Status & Inheritance & DNA Alteration & $\begin{array}{l}\text { Predicted protein } \\
\text { alteration in ZIC2 }\end{array}$ & $\begin{array}{l}\text { Functional } \\
\text { activity }\end{array}$ & Reference \\
\hline 39 & S & M & $P$ & Unknown & $\begin{array}{l}\text { c.910T } \rightarrow \text { A (Also SIX3: } \\
\text { c.850G } \rightarrow \text { C) }\end{array}$ & $\begin{array}{l}\text { p.W304R (Also SIX3: } \\
\text { p.A284P) }\end{array}$ & Predicted null & 18 \\
\hline 41 & U & M & $P$ & Unknown & c. $912 \mathrm{G} \rightarrow \mathrm{A}$ & p.W304X & Predicted null & 18 \\
\hline 42 & L & $\mathrm{F}$ & $P$ & De novo & $\mathrm{c.} .928 \mathrm{G} \rightarrow \mathrm{T}$ & p.E310X & Predicted null & 18 \\
\hline 43 & S & $\mathrm{F}$ & $P$ & De novo & c.932delG & p.G311AfsX102 & Predicted null & 1824 \\
\hline 46 & $\mathrm{U}$ & $U$ & $P$ & Unknown & c. $974 \mathrm{G} \rightarrow \mathrm{T}$ & p.R325L & Predicted null & 18 \\
\hline 47 & U & M & $\mathrm{P}$ & De novo & c. $.979 \mathrm{C} \rightarrow \mathrm{T}$ & p.H327Y & Predicted null & 18 \\
\hline 48 & S & M & $\mathrm{P}$ & De novo & c.994_1005dup & p.C335_P338dup & $\begin{array}{l}\text { Predicted loss-of- } \\
\text { function }\end{array}$ & This report \\
\hline 49 & $A$ & $\mathrm{~F}$ & $P$ & De novo & c. $1004 \mathrm{G} \rightarrow \mathrm{T}$ & p.C335F & Predicted null & 18 \\
\hline 50 & S & $\mathrm{F}$ & $P$ & De novo & c.1025_1026delAA & p.K342SfsX24 & Predicted null & 1831 \\
\hline 55 & $A$ & $M$ & $P$ & De novo & c. $1075+2 \mathrm{~T} \rightarrow \mathrm{A}(\mathrm{IVS}+1 \mathrm{~T} \rightarrow \mathrm{A})$ & p.G359fsX62 & Predicted null & 18 \\
\hline 56 & $U$ & $\mathrm{~F}$ & $P$ & Unknown & c.1076-1G $\rightarrow$ A (IVS1-1G $\rightarrow$ A) & Alternative splicing & Predicted null & 18 \\
\hline 57 & U & M & $P$ & De novo & c.1076-1G $\rightarrow$ A (IVS1-1G $\rightarrow A)$ & Alternative splicing & Predicted null & 18 \\
\hline 58 & S & M & $P$ & Unknown & c.1076-1G $\rightarrow$ A (IVS1-1G $\rightarrow$ A) & Alternative splicing & Predicted null & 18 \\
\hline 59 & $S$ & M & $P$ & Unknown & c. $1076-1 \mathrm{G} \rightarrow \mathrm{A}(\mathrm{IVS} 1-1 \mathrm{G} \rightarrow \mathrm{A})$ & Alternative splicing & Predicted null & 18 \\
\hline 60 & S & $\mathrm{F}$ & $P$ & De novo & c. $1090 \mathrm{C} \rightarrow \mathrm{T}$ & p.0364X & Predicted null & 18 \\
\hline $61 a$ & $S$ & M & $P$ (twin) & De novo & c.1091_1092delAG & p.0364LfsX2 & Predicted null & 182431 \\
\hline $61 b$ & u & M & Twin & De novo & c.1091_1092delAG & p.0364LfsX2 & Predicted null & 182431 \\
\hline 62 & $S$ & $\mathrm{M}$ & $P$ & Unknown & c.1095_1096delTG & p.C365X & Predicted null & 18 \\
\hline $63 a$ & S & $\mathrm{F}$ & $P$ & Maternal & c.1095_1096delTG & p.C365X & Predicted null & 18 \\
\hline $68 c$ & Mic & $\mathrm{F}$ & Mother & Unknown & c. $1206 \mathrm{C} \rightarrow \mathrm{G}$ & p.Y402X & Predicted null & 18 \\
\hline $69 a$ & S & $\mathrm{F}$ & $P$ & Maternal & c. $1208 \mathrm{C} \rightarrow \mathrm{A}$ & p.T403K & Predicted null & 18 \\
\hline $69 b$ & U & $\mathrm{F}$ & Half-sister & Maternal & c. $1208 \mathrm{C} \rightarrow \mathrm{A}$ (assumed) & p.T403K (assumed) & Predicted null & 18 \\
\hline $69 c$ & U & $\mathrm{F}$ & Half-sister & Maternal & c.1208C $\rightarrow$ A (assumed) & p.T403K (assumed) & Predicted null & 18 \\
\hline $69 d$ & $U$ & $\mathrm{~F}$ & Mother & Unknown & c. $1208 \mathrm{C} \rightarrow \mathrm{A}$ (assumed) & p.T403K (assumed) & Predicted null & 18 \\
\hline 70 & S & $M$ & $P$ & Unknown & c. $1211 \mathrm{~A} \rightarrow \mathrm{G}$ & p.H404R & Predicted null & 18 \\
\hline 71 & S & $\mathrm{F}$ & $P$ & Unknown & c. $1225 \mathrm{C} \rightarrow \mathrm{T}$ & p.R409W & Predicted null & 18 \\
\hline 72 & U & U & $P$ & Unknown & c. $1239+1 G \rightarrow C($ IVS1-1G $\rightarrow A)$ & $\begin{array}{l}\text { Possible inclusion of } \\
\text { intron } 2 \text { codons or } \\
\text { alternative splicing }\end{array}$ & Predicted null & 18 \\
\hline 73 & U & U & $P$ & Unknown & c. $1240-2 A \rightarrow G(I V S 2-2 A \rightarrow G)$ & Alternative splicing & Predicted null & 18 \\
\hline 74 & L & $M$ & $P$ & Unknown & $\mathrm{c} .1245 \mathrm{~T} \rightarrow \mathrm{G}$ & p.H4150 & Predicted null & 18 \\
\hline 75 & $S$ & $\mathrm{~F}$ & $P$ & Unknown & c.1277delC & p.P426RfsX129 & Predicted null & 18 \\
\hline 76 & $A$ & M & $\mathrm{P}$ & De novo & c.1313dupC & p.L440AfsX90 & Predicted null & 1718 \\
\hline 77 & L & $\mathrm{F}$ & $\mathrm{P}$ & De novo & c.1323dupG & p.S442Vfs 88 & $2 \%$ & 182429 \\
\hline 78 & $A$ & $M$ & $P$ & Unknown & c.1329delC & p.S444AfsX111 & Predicted null & This report \\
\hline 79 & MIHV & M & $P$ & De novo & c.1330_1365del & p.444_455del & $60 \%$ & 182429 \\
\hline 80 & S & M & $P$ & Unknown & c.1366_1395dup30 & p.A456_465dup & Unknown & This report \\
\hline 81 & MIHV & M & $\mathrm{P}$ & Unknown & c.1366_1395dup30 & p.A456_465dup & Unknown & This report \\
\hline $82 a$ & $A$ & M & $P$ & $\begin{array}{l}\text { Paternal (assumed } \\
\text { germline mosaicism) }\end{array}$ & c.1377_1406dup30 & p.A461_470dup & $\begin{array}{l}5 \% \text { with reduced } \\
\text { DNA binding }\end{array}$ & 171824 \\
\hline $82 b$ & $A$ & $\mathrm{~F}$ & Sister & $\begin{array}{l}\text { Paternal (assumed } \\
\text { germline mosaicism) }\end{array}$ & c.1377_1406dup30 & p.A461_470dup & $\begin{array}{l}5 \% \text { with reduced } \\
\text { DNA binding }\end{array}$ & 171824 \\
\hline $82 c$ & $u$ & M & $\begin{array}{l}\text { Paternal } \\
\text { half-sister }\end{array}$ & $\begin{array}{l}\text { Paternal (assumed } \\
\text { germline mosaicism) }\end{array}$ & c.1377_1406dup30 (assumed) & $\begin{array}{l}\text { p.A461_470dup } \\
\text { (assumed) }\end{array}$ & $\begin{array}{l}5 \% \text { with reduced } \\
\text { DNA binding }\end{array}$ & 171824 \\
\hline
\end{tabular}


Table 2 Continued

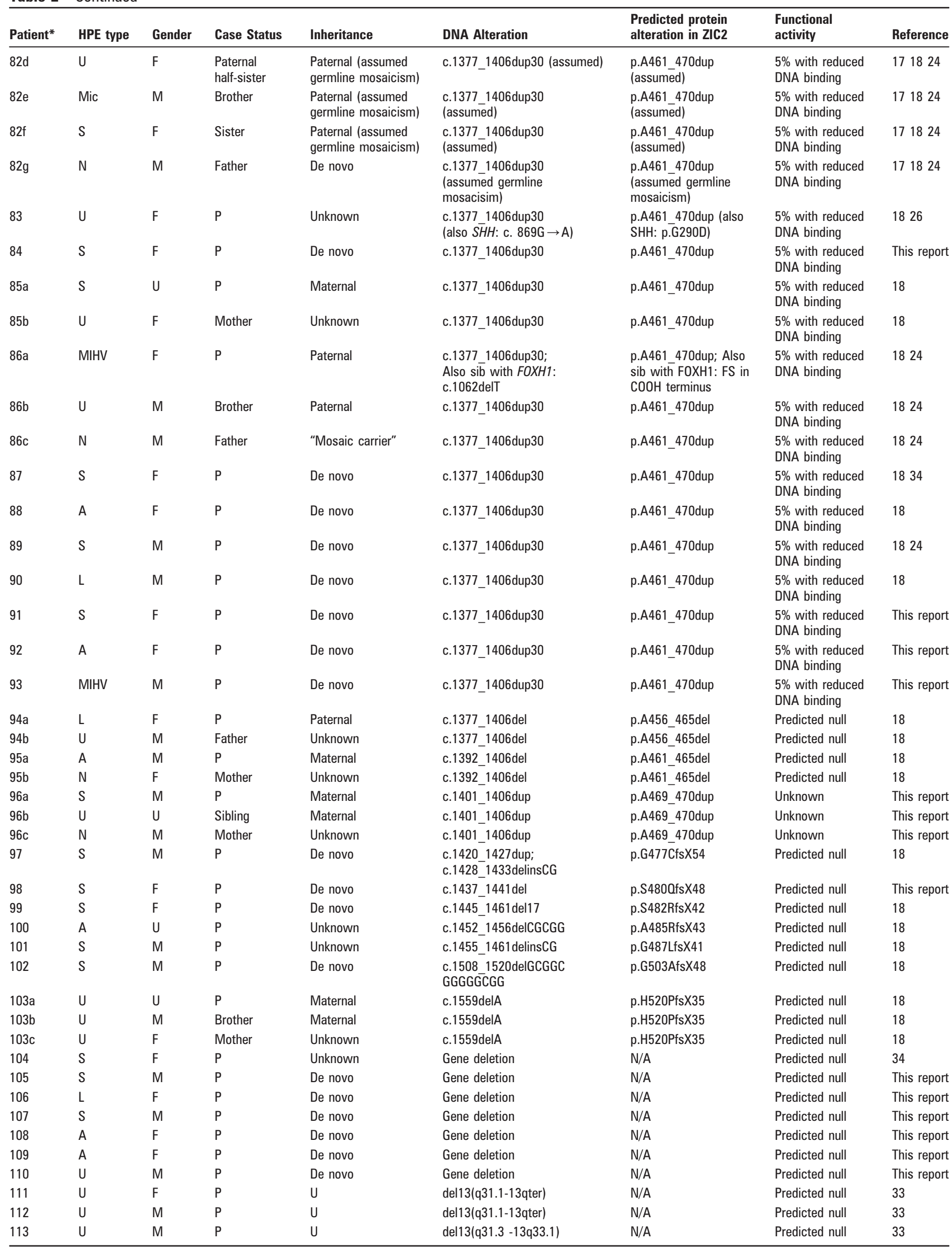


Table 2 Continued

\begin{tabular}{|c|c|c|c|c|c|c|c|c|}
\hline Patient* & HPE type & Gender & Case Status & Inheritance & DNA Alteration & $\begin{array}{l}\text { Predicted protein } \\
\text { alteration in ZIC2 }\end{array}$ & $\begin{array}{l}\text { Functional } \\
\text { activity }\end{array}$ & Reference \\
\hline 114 & U & M & $P$ & $U$ & $\operatorname{del} 13(q 32.3)$ & $\mathrm{N} / \mathrm{A}$ & Predicted null & 33 \\
\hline 115 & $A$ & $\mathrm{~F}$ & $P$ & $U$ & del13(q32q34) & $\mathrm{N} / \mathrm{A}$ & Predicted null & 32 \\
\hline 116 & $A$ & $\mathrm{~F}$ & $P$ & Maternal & $\mathrm{i}(13)(q 10)$ & $\mathrm{N} / \mathrm{A}$ & Predicted null & 25 \\
\hline 117 & U & U & $P$ & $U$ & del(13)(q22qter) & N/A & Predicted null & 16 \\
\hline 118 & $A$ & M & $P$ & $U$ & del(13)(q22qter) & N/A & Predicted null & 27 \\
\hline 119 & U & M & $P$ & U & del(13)(q31qter) & $\mathrm{N} / \mathrm{A}$ & Predicted null & 30 \\
\hline
\end{tabular}

*Each kindred is listed by a separate number; individuals within a kindred are each assigned a separate letter.

A, alobar; F, female; L, lobar; M, male; Mic: microform; MIHV, middle interhemispheric variant; N, none; P, proband; S, semilobar; U, unknown.

Independent reviews (by $\mathrm{KR}, \mathrm{BS}, \mathrm{MM}$ ) of photos of available probands with mutations in ZIC2 revealed a common phenotype consisting of bitemporal narrowing (53\%), upslanting palpebral fissures (97\%), a flat nasal bridge (33\%), a short nose with anteverted nares (73\%), a broad and deep philtrum (43\%), and the subjective appearance of relatively large ears $(37 \%)$ (figure 2, table 5). All photos reviewed showed evidence of this common facial phenotype, and none had facial features notably similar to those of patients with HPE due to mutations in other genes. Prevalences of facial findings with data sufficient for comparison are presented in table 6 compared to a cohort with mutations in SIX3.

Although additional photos were not available for review, a similar facial phenotype was independently described by collaborators (SM, SO, personal communication). On review, this facial phenotype also occurs in previously published patients with mutations in ZIC2. ${ }^{17} 24$ Facial clefts, ranging from cleft lip and palate to a small unilateral nostril cleft, were described in $10 \%$, while $17 \%$ did not have clefts, but had high palates. Facial clefts in patients with intragenic ZIC2 mutations are approximately a third as common as in other cohorts with non-ZIC2 related HPE. ${ }^{8} 21$

In terms of neurological defects, in addition to HPE in patients with intragenic sequence determined mutations (ie, not including patients with whole gene deletions or large cytogenetic imbalances), $12 \%$ of individuals had hydrocephalus, and $4 \%$ were reported as having neural tube defects. Finally, in terms of nonneurological manifestations, 14\% had skeletal anomalies, 9\% had cardiac anomalies, $7 \%$ had renal anomalies, $7 \%$ had genital anomalies, $4 \%$ had gastrointestinal anomalies, and $4 \%$ had pulmonary anomalies. Five per cent had more than three congenital anomalies in these systems, including complex congenital cardiac, renal, and skeletal abnormalities. We present comparisons to the only other large cohort of patients with HPE due to mutations in a single gene (SIX3) and to a cohort of patients with non-syndromic HPE (table 6). In this latter comparison, the category of non-syndromic HPE includes patients in whom HPE does not occur in the context of a broader syndrome, but it is

Table 3 Prevalences of holoprosencephaly (HPE) types

\begin{tabular}{llll}
\hline HPE type & $\begin{array}{l}\text { Patients with } \\
\text { mutations in }\end{array}$ & $\begin{array}{l}\text { Probands with } \\
\text { mutations in } \\
\text { ZIC2, n (\%) }\end{array}$ & $\begin{array}{l}\text { Patients with } \\
\text { deletions of }\end{array}$ \\
\hline ZIC2, n (\%)
\end{tabular}

MIHV, middle interhemispheric variant. important to realise that patients with non-syndromic HPE may present with findings that extend beyond the traditional craniofacial and structural brain anomalies most often recognised as the classic manifestations of autosomal dominant monogenic HPE. ${ }^{21}$ While not all features were described in the three cohorts, the comparisons do show statistical support that patients with mutations in ZIC2 appear to have a unique facial phenotype. Additionally, this comparison shows that patients with mutations in ZIC2 have overall similar rates of extra-neuronal manifestations to patients with SIX3 mutations in contrast to a cohort of patients with non-syndromic HPE, although skeletal manifestations appear more frequent in patients with mutations in ZIC2 than in SIX3 related HPE. 821

\section{Genotypic and functional analysis}

The molecular findings among patients with mutations in ZIC2 have been recently and extensively analysed. ${ }^{18}$ Among kindreds with intragenic sequence determined mutations, $81 \%$ were unique. One mutation, which resulted in an alanine expansion and which has been shown to result in greatly reduced function, occurred in 12 apparently unrelated kindreds.

Among the 103 unrelated kindreds with intragenic sequence determined mutations, 37\% had frameshift mutations, $21 \%$ had missense mutations, $17 \%$ were in-frame duplications or insertions, $16 \%$ had nonsense mutations, $6 \%$ were predicted to result in alternative splicing, and 3\% were in-frame deletions; $89 \%$ of the in-frame deletions and duplications occurred in the polyalanine segment of the gene.

The vast majority (98\%) of family specific mutations were predicted or proven significant loss-of-function. Interestingly, among the very few patients (kindreds 3, 16, and 79) whose mutations were shown by functional analysis not to be null, alobar HPE was not observed and 66\% (2/3) were inherited, in contrast to the overall estimation that $72 \%$ of mutations in probands occur de novo. Due to the low number of kindreds with mutations not shown to be null and the fact that equivalent functional analyses have not been performed for most mutations, statistical calculations involving the latter observation were not attempted. The overall rate of de novo mutations in ZIC2 is in stark contrast to patients with HPE due to mutations in $\mathrm{SHH}$ or $\mathrm{SIX} 3$, in which the de novo mutation rate is estimated to be $10-30 \%$, and $14 \%$, respectively (Muenke lab, unpublished data, 2010). ${ }^{21}$

In our analysis, we did not include previously reported variants in ZIC2 resulting in different numbers of histidine repeats, which had been thought to be pathogenic, but on later pedigree analysis, are now thought to be polymorphisms that may be common in ethnicities not originally part of control populations. ${ }^{18} 3536$

\section{DISCUSSION}

Mutations in ZIC2 are one of the two most common single gene causes of non-syndromic HPE. We show that patients with ZIC2 
Figure 1 Characteristic findings on neuroimaging. (A) Alobar

holoprosencephaly (HPE), with shunt in place. $(B, C)$ Semilobar HPE with large dorsal cyst. (D) Semilobar HPE without dorsal cyst. (E, F) Middle interhemispheric variant (MIHV) type HPE.
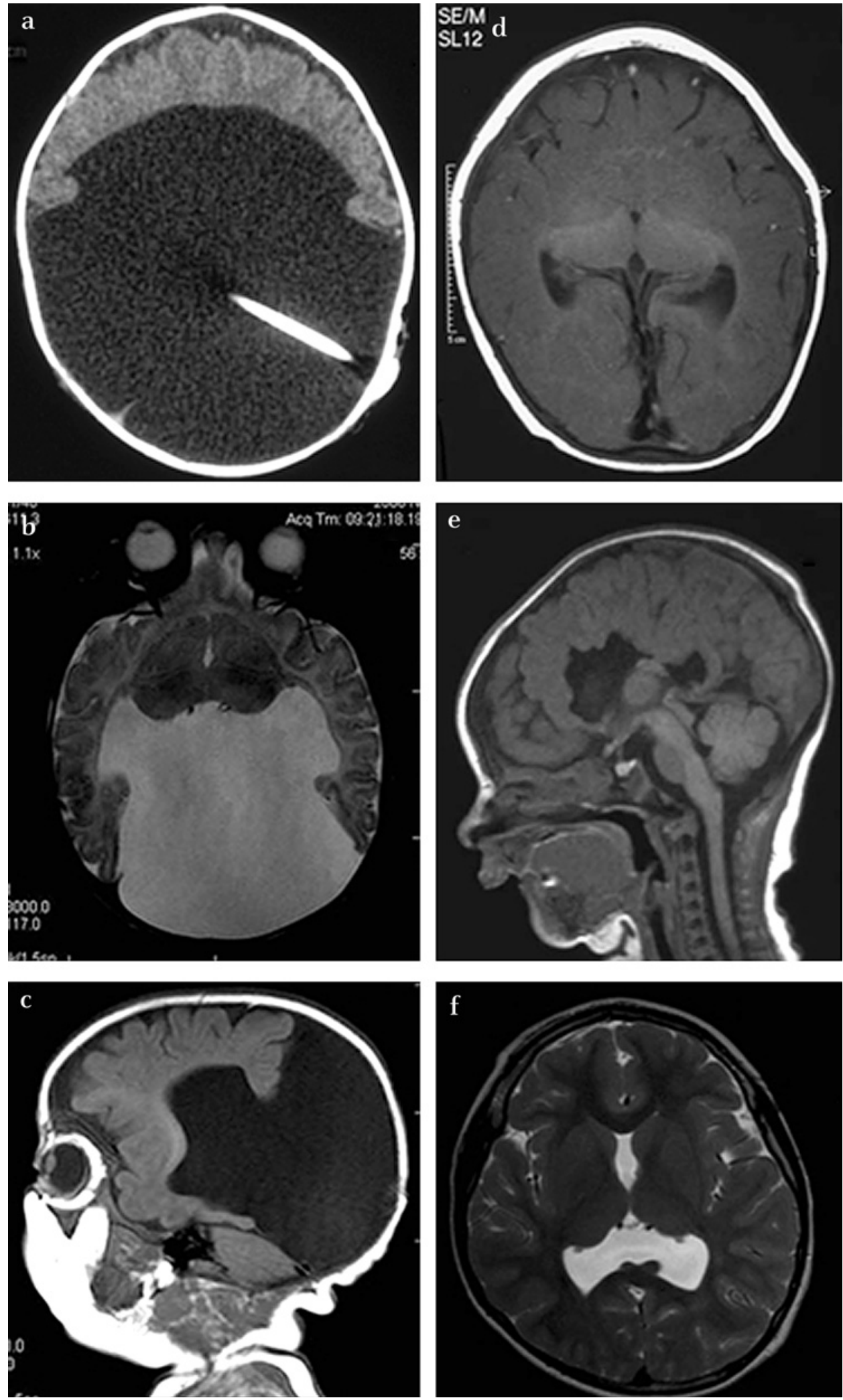

mutations do not typically have facial dysmorphisms standardly associated with HPE. HPE due to ZIC2 mutations could be underappreciated, as HPE is not diagnosed in some patients with ZIC2 mutations due to the absence of facial dysmorphisms leading to a diagnosis of HPE.

Further, our analysis of this large cohort reveals several unique features which distinguishes ZIC2 related HPE from HPE due to other causes. First, the recognition that many patients with mutations in ZIC2 have a subtle but distinct facial phenotype may help aid diagnosis. This facial appearance has not been described in patients with HPE resulting from other genetic aetiologies. The data in our cohort may be biased because only some patients survived long enough for photographs to be taken. However, the fact that no photographs demonstrated a combination of features 
Table 4 Comparison of holoprosencephaly (HPE) type distribution among the three 'classic' HPE types for the patients with intragenic ZIC2 mutations, as well as two sources from the literature and a source obtained from our database: Lazaro et al (2004) described a cohort of both living patients and deceased fetuses with non-chromosomal, non-syndromic HPE, while Orioli et al (2007) describes a cohort of patients born with HPE. ${ }^{78}$ We also compare our cohort of patients with mutations in ZIC2 with a cohort of prospectively ascertained probands with non-chromosomal, non-syndromic HPE whose samples were sent to the National Institutes of Health (NIH) over approximately a 3 year period. Due to low prevalence, middle interhemispheric variant (MIHV) was not considered

\begin{tabular}{|c|c|c|c|c|}
\hline & $\begin{array}{l}\text { Intragenic ZIC2 } \\
\text { mutations n (\%) }\end{array}$ & Lazaro et al $\mathrm{n}(\%)$ & $\begin{array}{l}\text { Orioli and Castilla } \\
\text { n (\%) }\end{array}$ & NIH n (\%) \\
\hline Alobar & $28(32)$ & $15(22)$ & $33(40)$ & $10(13)$ \\
\hline Semilobar & $48(55)$ & $31(45)$ & $36(43)$ & $45(6)$ \\
\hline Total & 87 & 69 & 83 & 75 \\
\hline Comparison vs ZIC2 cohort & & $\chi_{(2)}^{2}=9.88, p=0.0077$ & $\chi_{(2)}^{2}=2.39, p=0.30$ & $\chi_{(2)}^{2}=10.4, p=0.0055$ \\
\hline
\end{tabular}

Alobar
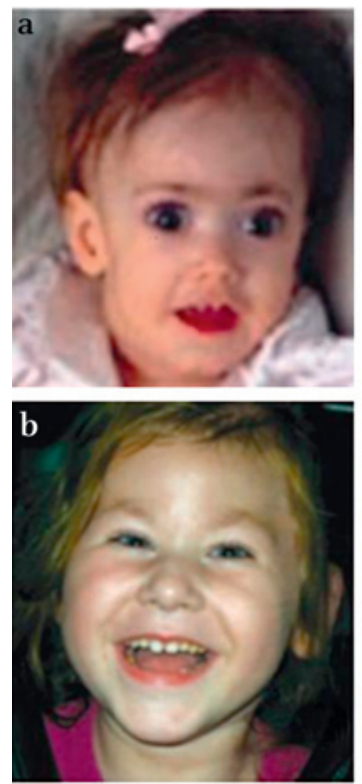
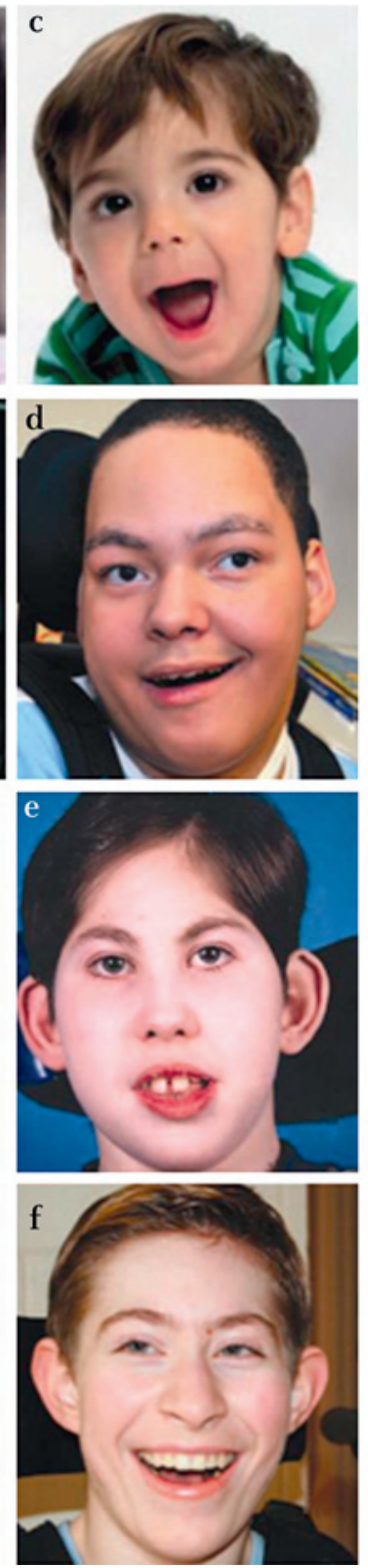

Semilobar
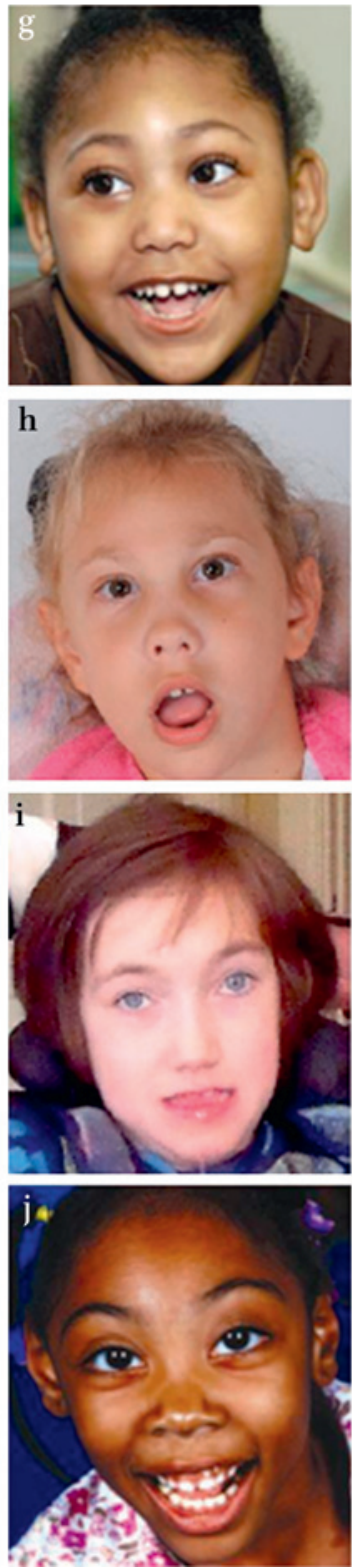
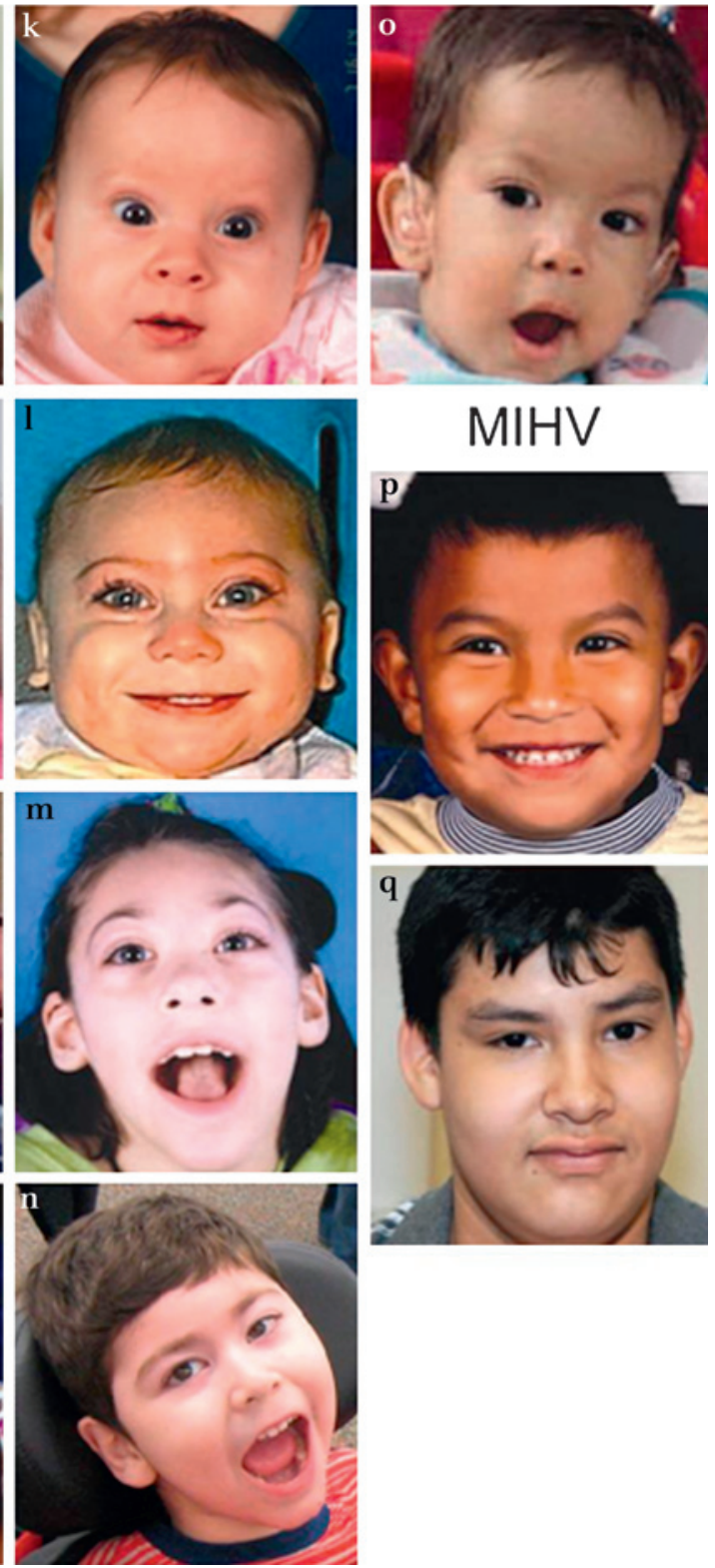

Figure 2 Patients with mutations in ZIC2, arranged by holoprosencephaly (HPE) type. Letters link to patients described in tables 2 and 5 . Note the pattern of facial findings in patients with mutations in ZIC2, consisting of bitemporal narrowing, upslanting palpebral fissures, flat nasal bridge, a short nose with upturned nares, a broad and/or deep philtrum, and the appearance of large ears. MIHV, middle interhemispheric variant. 
Table 5 Description of common dysmorphic features in probands with photos available for review. Image references are shown in the far right column, with the corresponding identifier for table 2 and figure 2. Images were independently reviewed by three co-authors (KR, BS, MM)

\begin{tabular}{|c|c|c|c|c|c|c|c|c|c|c|c|}
\hline Patient & HPE type & BN & USPF & FNB & SNAN & BDP & LE* $^{*}$ & Other & $\begin{array}{l}\text { Reference } \\
\text { (for images) }\end{array}$ & figure 2 & table 2 \\
\hline 1 & $A$ & + & + & + & + & + & & Synophrys & This report & a & 49 \\
\hline 2 & $A$ & & + & + & + & & & & This report & $b$ & 108 \\
\hline 3 & A & + & + & + & + & + & & Tall forehead & This report & N/A & 24 \\
\hline 4 & A & + & + & & & + & & & This report & N/A & 27 \\
\hline 5 & $A$ & + & + & + & + & + & & & 17 & $\mathrm{~N} / \mathrm{A}$ & 52 \\
\hline 6 & A & & + & & & & + & Sloping forehead & 17 & $\mathrm{~N} / \mathrm{A}$ & $82 a$ \\
\hline 7 & A & & + & & + & & + & Sloping forehead & This report & $\mathrm{N} / \mathrm{A}$ & $82 b$ \\
\hline 8 & S & & + & & + & & & & This report & c & 2 \\
\hline 9 & S & + & & & & + & & Tall, narrow head, exotropia & This report & $d$ & 62 \\
\hline 10 & S & + & + & & + & & + & & This report & e & $28 \mathrm{a}$ \\
\hline 11 & S & & + & & & & + & Synophrys & This report & $f$ & 102 \\
\hline 12 & S & + & + & + & + & + & & & This report & $\mathrm{g}$ & $68 a$ \\
\hline 13 & S & & + & & + & + & + & Slight synophrys, cupid-bow upper lip & This report & $\mathrm{h}$ & 22 \\
\hline 14 & $S$ & & + & + & & & & Broad forehead & This report & i & 45 \\
\hline 15 & S & & + & + & + & & & & This report & j & 91 \\
\hline 16 & S & & + & & + & + & & & This report & $\mathrm{k}$ & 26 \\
\hline 17 & S & & + & & + & & + & Synophrys & This report & I & 59 \\
\hline 18 & S & & + & & + & & + & & This report & $\mathrm{m}$ & 99 \\
\hline 19 & S & & + & & + & & + & & This report & $\mathrm{n}$ & 48 \\
\hline 20 & S & + & + & + & + & + & + & Tall, broad forehead & This report & 0 & 58 \\
\hline 21 & S & + & + & & & + & & Tall forehead, dysplastic ears & This report & N/A & 64 \\
\hline 22 & S & + & + & & & & & & This report & $\mathrm{N} / \mathrm{A}$ & $19 a$ \\
\hline 23 & S & + & + & & & + & & & This report & $\mathrm{N} / \mathrm{A}$ & $19 b$ \\
\hline 24 & S & + & + & & + & & + & Tall forehead & 24 & N/A & 89 \\
\hline 25 & S & + & + & & + & + & & & 24 & $\mathrm{~N} / \mathrm{A}$ & $61 a$ \\
\hline 26 & S & + & + & + & + & & & Triangular mouth, myopathic facies & 24 & N/A & 43 \\
\hline 27 & L & + & + & + & + & & & & 24 & $\mathrm{~N} / \mathrm{A}$ & $16 a$ \\
\hline 28 & MIHV & & + & & + & & + & & This report & $\mathrm{p}$ & 93 \\
\hline 29 & MIHV & & + & & + & & & & $\begin{array}{l}\text { This report (pictured in reference }{ }^{24} \\
\text { at younger age) }\end{array}$ & $q$ & 79 \\
\hline 30 & Unknown & + & + & & + & + & & Tall forehead & This report & N/A & 110 \\
\hline
\end{tabular}

*Measurements not universally available; and are the subjective judgement of independent dysmorphologists.

BDP, broad or deep philtrum; BN, bitemporal narrowing; FNB, flat nasal bridge; LE, large ears; MIHV, middle interhemispheric variant; SNAN, short nose and/or anteverted nares; USPF, upslanting palpebral fissures.

more commonly associated with HPE, such as severe hypotelorism, flat nasal bridge, cleft lip/palate, or SMCI, is striking. Although the retrospective data do not allow certain comparisons to be made, available statistical calculations show evidence that the facial phenotype in patients with ZIC2 mutations is different than that of other cohorts of patients with HPE.

Second, unlike other genes associated with HPE, the majority of mutations in ZIC2 occur de novo. Our data suggest the presence of at least five families in which germline mosaicism appears to be causative of HPE in a child, which has important implications for genetic counselling. Parents who test negative for ZIC2 mutations through analysis of peripheral blood may still be at risk for having other affected children.

Third, along these lines, we did not identify any large pedigrees in which numerous individuals from multiple generations were found to have a mutation, which is strikingly different from what has been observed with other common HPE associated genes such as SHH or SIX3. This could imply that mutations in ZIC2 are less likely to result in mildly affected individuals than mutations in other HPE associated genes, and again is important for genetic counselling.

Finally, our findings show that non-chromosomal, non-syndromic HPE is not simply an 'above-the-neck' diagnosis. Patients with mutations in ZIC2 frequently have other organ systems involved, and clinicians must look beyond craniofacial and structural brain anomalies in their clinical assessment.
While skeletal anomalies may be more frequent in patients with ZIC2 than in other types of non-chromosomal, non-syndromic HPE, no clear overall pattern emerges except that it is important to be aware that congenital anomalies may be found in other major organ systems.

One shortcoming of this report is that the available retrospective collection of clinical data was not uniform. For this reason, it is likely that we underestimate the prevalence of many of the findings (such as neural tube defects and other congenital anomalies). Despite the challenges in synthesising the data, the availability of a large cohort of patients with mutations affecting the same gene greatly enriches our understanding of HPE in general and ZIC2 in particular. This analysis reveals a previously unnoticed ZIC2 specific phenotype and highlights the importance of a comprehensive and collaborative approach in studying HPE and other complex genetic disorders.

\section{Author affiliations}

${ }^{1}$ National Human Genome Research Institute, National Institutes of Health, Bethesda, Maryland, USA

${ }^{2}$ Department of Pathology, State University of New York-Downstate Medical Center, Brooklyn, New York, USA

${ }^{3}$ CNRS Génétique et Développement, Université de Rennes, 35043 Rennes Cedex, France

${ }^{4}$ Service de génétique clinique, CHU Hôpital Sud, 35043 Rennes Cedex, France ${ }^{5}$ Department of Neurology, Texas Scottish Rite Hospital for Children, University of Texas Southwestern Medical Center, Dallas, Texas, USA

${ }^{6}$ Department of Genetics, Children's National Medical Center, Washington, DC, USA 
Table 6 Findings (beyond holoprosencephaly (HPE) type) in patients with mutations in ZIC2 with sufficient data for analysis of findings versus reported findings in patients with mutations in $S I X 3(n=91$ for facial findings, $n=83$ for other findings) and separately for a cohort of patients with non-syndromic HPE $(n=258) .{ }^{8}{ }^{21}$ In this latter comparison, non-syndromic HPE includes patients in whom HPE does not occur in the context of a broader syndrome, but patients may still present with findings beyond the traditional craniofacial and structural brain anomalies most commonly recognised as classic features of autosomal dominant monogenic $\mathrm{HPE}^{21}$

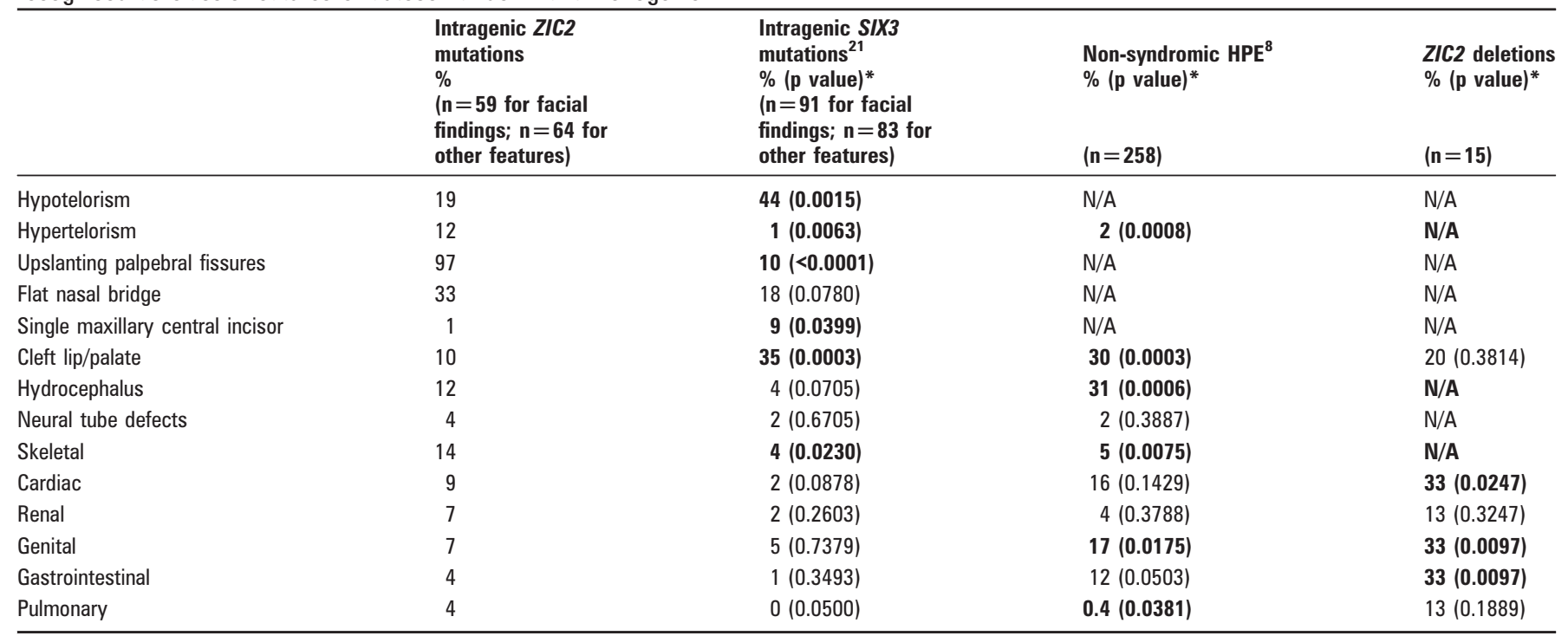

Statistical significance is shown in the right-most column, and statistically significant differences are shown in bold. Certain features were not analysed in all cohorts, so a comparison was not possible. Values with significantly different $\mathrm{p}$ values are shown in bold.

*Two-tailed p value by Fisher's exact test, compared to cohort of patients with mutations in ZIC2.

${ }^{7}$ Department of Medical Genetics, Munroe-Meyer Institute for Genetics and Rehabilitation, University of Nebraska Medical Center, Omaha, Nebraska, USA

${ }^{8}$ Practice of Human Genetics, Linden, Germany

${ }^{9}$ Center for and Department of Human Genetics, University of Regensburg, Regensburg, Germany

${ }^{10} \mathrm{GeneDx}$, Gaithersburg, Maryland, USA

${ }^{11}$ Department of Clinical Genetics, Maastricht University Medical Centre (MUMC+),

Maastricht, The Netherlands

${ }^{12}$ GROW, School for Oncology and Developmental Biology, MUMC+, Maastricht, The Netherlands

${ }^{13}$ Department of Obstetrics and Gynecology, University of North Carolina School of Medicine, Chapel Hill, North Carolina, USA

${ }^{14}$ Clinic of Metabolic Diseases, Endocrinology and Diabetology, The Children's Memorial Health Institute, Warsaw, Poland

${ }^{15}$ Department of Genetics, University of Pittsburgh Medical Center, Pittsburgh, Pennsylvania, USA

${ }^{16}$ Department of Genetics, Marshfield Clinic, Marshfield, Wisconsin, USA

${ }^{17}$ Clinical and Molecular Genetics Unit, Institute of Child Health, Great Ormond Street Hospital for Children, UCL, London, UK

${ }^{18}$ Department of Pediatrics, Academic Medical Center, Amsterdam, Netherlands

${ }^{19}$ Department of Neurology, Stanford University School of Medicine, Palo Alto,

California, USA

${ }^{20}$ Kennedy Krieger Institute, Johns Hopkins University, Baltimore, Maryland, USA

${ }^{21}$ Institute of Human Genetics, University Duisburg-Essen, Essen, Germany

${ }^{22}$ Department of Pediatrics, Division of Genetics and Metabolic Disorders, University of

Texas Health Science Center at San Antonio, San Antonio, Texas, USA

${ }^{23}$ Institute of Social Pediatric and Adolescent Medicine of the University of Munich,

Munich, Germany

${ }^{24}$ Practice of Human Genetics, Berlin, Germany

${ }^{25}$ Department of Genetics, Lutheran General Hospital, Park Ridge, Illinois, USA

${ }^{26}$ Department of Obstetrics and Gynecology, Drexel University College of Medicine, Philadelphia, Pennsylvania, USA

${ }^{27}$ Clinical Genetics, Addenbrooke's Treatment Centre, Addenbrooke's Hospital, Cambridge, UK

${ }^{28}$ Department of Epidemiology, Johns Hopkins Bloomberg School of Public Health, Baltimore, Maryland, USA

Acknowledgements We would like to express our deep gratitude to the patients and families who participated in these studies. The authors would also like to thank all of the members of the Carter Centers for Brain Research in Holoprosencephaly and Related Malformations.

Funding This research was supported by the Division of Intramural Research, National Human Genome Research Institute, National Institutes of Health, Department of
Health and Human Services, United States of America and GIS Maladies Rares GISMR0701/DHOS, France. Other Funders: NIH; Howard Hughes Medical Institute.

\section{Competing interests None}

\section{Patient consent Obtained.}

Ethics approval This study was conducted with the approval of the National Human Genome Research Institute, National Institutes of Health, Bethesda, MD, USA.

Provenance and peer review Not commissioned; externally peer reviewed.

\section{REFERENCES}

1. Matsunaga E, Shiota K. Holoprosencephaly in human embryos: epidemiologic studies of 150 cases. Teratology 1977;16:261-72.

2. Leoncini E, Baranello G, Orioli IM, Annerén G, Bakker M, Bianchi F, Bower C, Canfield MA, Castilla EE, Cocchi G, Correa A, De Vigan C, Doray B, Feldkamp ML, Gatt M, Irgens LM, Lowry RB, Maraschini A, Mc Donnell R, Morgan M, Mutchinick O, Poetzsch S, Riley M, Ritvanen A, Gnansia ER, Scarano G, Sipek A, Tenconi R, Mastroiacovo P. Frequency of holoprosencephaly in the International Clearinghouse Birth Defects Surveillance Systems: Searching for population variations. Birth Defects Res A Clin Mol Teratol 2008;82:585-91.

3. Muenke M, Beachy PA. Genetics of ventral forebrain development and holoprosencephaly. Curr Opin Genet Dev 2000;10:262-9.

4. Cohen MM Jr. Holoprosencephaly: clinical, anatomic, and molecular dimensions. Birth Defects Res A Clin Mol Teratol 2006;76:658-73.

5. Barkovich AJ, Quint DJ. Middle interhemispheric fusion: an unusual variant of holoprosencephaly. AJNR Am J Neuroradiol 1993:14:431-40.

6. Dubourg C, Bendavid C, Pasquier L, Henry C, Odent S, David V. Holoprosencephaly. Orphanet J Rare Dis 2007;2:8.

7. Lazaro L, Dubourg C, Pasquier L, Le Duff F, Blayau M, Durou MR, de la Pintière AT, Aguilella C, David V, Odent S. Phenotypic and molecular variability of the holoprosencephalic spectrum. Am J Med Genet 2004;129A:21-4.

8. Orioli IM, Castilla EE. Clinical epidemiologic study of holoprosencephaly in South America. Am J Med Genet A 2007;143A:3088-99.

9. Cohen MM Jr. Perspectives on holoprosencephaly: Part I. Epidemiology, genetics, and syndromology. Teratology 1989;40:211-35.

10. Cohen MM Jr, Sulik KK. Perspectives on holoprosencephaly: Part II. Central nervous system, craniofacial anatomy, syndrome commentary, diagnostic approach, and experimental studies. J Craniofac Genet Dev Biol 1992;12:196-244.

11. Edison RJ, Muenke M. Mechanistic and epidemiologic considerations in the evaluation of adverse birth outcomes following gestational exposure to statins. Am J Med Genet 2004;131:287-98.

12. Edison RJ, Muenke M. Central nervous system and limb anomalies in case reports of first-trimester statin exposure. N Engl J Med 2004;350:1579-82. Erratum in: N Engl J Med 2005;352:2759. 
13. Croen LA, Shaw GM, Lammer EJ. Holoprosencephaly: epidemiologic and clinical characteristics of a California population. Am J Med Genet 1996;64:465-72.

14. Collins AL, Lunt PW, Garrett C, Dennis NR. Holoprosencephaly: a family showing dominant inheritance and variable expression. J Med Genet 1993;30:36-40.

15. Brown S, Gersen S, Anyane-Yeboa K, Warburton D. Preliminary definition of a "critical region" of chromosome 13 in q32: report of 14 cases with $13 q$ deletions and review of the literature. Am J Med Genet 1993:45:52-9.

16. Brown S, Russo J, Chitayat D, Warburton D. The 13q- syndrome: the molecular definition of a critical deletion region in band 13q32. Am J Hum Genet 1995;57:859-66.

17. Brown SA, Warburton D, Brown LY, Yu CY, Roeder ER, Stengel-Rutkowski S, Hennekam RC, Muenke M. Holoprosencephaly due to mutations in ZIC2. a homologue of Drosophila odd-paired. Nat Genet 1998;20:180-3.

18. Roessler E, Lacbawan F, Dubourg C, Paulussen A, Herbergs J, Hehr U, Bendavid C, Zhou N, Ouspenskaia M, Bale S, Odent S, David V, Muenke M. The full spectrum of holoprosencephaly-associated mutations within the ZIC2 gene in humans predicts loss- of-function as the predominant disease mechanism. Hum Mutat 2009;30: E541-54.

19. Cheng X, Hsu CM, Currle DS, Hu JS, Barkovich AJ, Monuki ES. Central roles of the roof plate in telencephalic development and holoprosencephaly. J Neurosci 2006;26:7640-9.

20. Warr N, Powles-Glover N, Chappell A, Robson J, Norris D, Arkell RM. Zic2associated holoprosencephaly is caused by a transient defect in the organizer region during gastrulation. Hum Mol Genet 2008;17:2986-96.

21. Lacbawan F, Solomon BD, Roessler E, El-Jaick K, Domené S, Vélez JI, Zhou N, Hadley D, Balog JZ, Long R, Fryer A, Smith W, Omar S, McLean SD, Clarkson K, Lichty A, Clegg NJ, Delgado MR, Levey E, Stashinko E, Potocki L, Vanallen MI, Clayton-Smith J, Donnai D, Bianchi DW, Juliusson PB, Niølstad PR, Brunner HG, Carey JC, Hehr U, Müsebeck J, Wieacker PF, Postra A, Hennekam RC, van den Boogaard MJ, van Haeringen A, Paulussen A, Herbergs J, Schrander-Stumpel CT, Janecke AR, Chitayat D, Hahn J, McDonald-McGinn DM, Zackai EH, Dobyns WB, Muenke M. Clinical spectrum of SIX3-associated mutations in holoprosencephaly: correlation between genotype, phenotype, and function. J Med Genet 2009:46:389-98.

22. Elms $\mathbf{P}$, Siggers $P$, Napper D, Greenfield A, Arkell R. Zic2 is required for neural crest formation and hindbrain patterning during mouse development. Dev Biol 2003;264:391-406.

23. Nagai T, Aruga J, Minowa O, Sugimoto T, Ohno Y, Noda T, Mikoshiba K. Zic2 regulates the kinetics of neurulation. Proc Natl Acad Sci U S A 2000:97:1618-23.

24. Brown LY, Odent S, David V, Blayau M, Dubourg C, Apacik C, Delgado MA, Hall BD, Reynolds JF, Sommer A, Wieczorek D, Brown SA, Muenke M. Holoprosencephaly due to mutations in ZIC2: alanine tract expansion mutations may be caused by parental somatic recombination. Hum Mol Genet 2001;10:791-6.

25. Chen CP, Chern SR, Lee CC, Chen LF, Chuang CY, Chen MH. Prenatal diagnosis of de novo isochromosome $13 q$ associated with microcephaly, alobar holoprosencephaly and cebocephaly in a fetus. Prenat Diagn 1998;18:393-8.

26. Nanni L, Ming JE, Bocian M, Steinhaus K, Bianchi DW, Die-Smulders C, Giannotti A, Imaizumi K, Jones KL, Campo MD, Martin RA, Meinecke P, Pierpont ME, Robin NH Young ID, Roessler E, Muenke M. The mutational spectrum of the sonic hedgehog gene in holoprosencephaly: SHH mutations cause a significant proportion of autosomal dominant holoprosencephaly. Hum Mol Genet 1999;8:2479-88.

27. Gutierrez J, Sepulveda W, Saez R, Carstens E, Sanchez J. Prenatal diagnosis of $13 q$ - syndrome in a fetus with holoprosencephaly and thumb agenesis. Ultrasound Obstet Gynecol 2001;17:166-8.

28. Orioli IM, Castilla EE, Ming JE, Nazer J, Burle de Aguiar MJ, Llerena JC, Muenke M. Identification of novel mutations in SHH and ZIC2 in a South American (ECLAMC) population with holoprosencephaly. Hum Genet 2001;109:1-6.

29. Brown L, Paraso M, Arkell R, Brown S. In vitro analysis of partial loss-of-function ZIC2 mutations in holoprosencephaly: alanine tract expansion modulates DNA binding and transactivation. Hum Mol Genet 2005;14:411-20.

30. Marcorelles P, Loget P, Fallet-Bianco C, Roume J, Encha-Razavi F, Delezoide AL. Unusual variant of holoprosencephaly in monosomy 13q. Pediatr Dev Pathol 2002;5:170-8.

31. Dubourg C, Lazaro L, Pasquier L, Bendavid C, Blayau M, Le Duff F, Durou MR, Odent S, David V. Molecular screening of SHH, ZIC2, SIX3, and TGIF genes in patients with features of holoprosencephaly spectrum: Mutation review and genotypephenotype correlations. Hum Mutat 2004;24:43-51.

32. Araujo Júnior E, Filho HA, Pires CR, Filho SM. Prenatal diagnosis of the $13 q$ - syndrome through three-dimensional ultrasonography: a case report. Arch Gynecol Obstet 2006:274:243-5.

33. Quélin C, Bendavid C, Dubourg C, de la Rochebrochard C, Lucas J, Henry C, Jaillard S, Loget P, Loeuillet L, Lacombe D, Rival JM, David V, Odent S, Pasquier L. Twelve new patients with $13 q$ deletion syndrome: genotype-phenotype analyses in progress. Eur J Med Genet 2009;52:41-6.

34. Paulussen A, Tserpelis D, Spierts S, Smeets H, Herbergs J. Holoprosencephaly mutations in the Dutch population [abstract]. Eur Soc of Hum Genet 2008.

35. Brown LY, Hodge SE, Johnson WG, Guy SG, Nye JS, Brown S. Possible association of NTDs with a polyhistidine tract polymorphism in the ZIC2 gene. Am J Med Genet 2002;108:128-31.

36. Zhu H, Junker WM, Finnell RH, Brown S, Shaw GM, Lammer EJ, Canfield M, Hendricks K. Lack of association between ZIC2 and ZIC3 genes and the risk of neural tube defects (NTDs) in Hispanic populations. Am J Med Genet A 2003;116A:414-15. 


\section{JMG}

Mutations in ZIC2 in human

holoprosencephaly: description of a Novel ZIC2 specific phenotype and comprehensive analysis of 157 individuals

Benjamin D Solomon, Felicitas Lacbawan, Sandra Mercier, et al.

J Med Genet 2010 47: 513-524 originally published online December 2, 2009

doi: 10.1136/jmg.2009.073049

Updated information and services can be found at:

http://jmg.bmj.com/content/47/8/513.full.html

These include:

References This article cites 35 articles, 9 of which can be accessed free at: http://jmg.bmj.com/content/47/8/513.full.html\#ref-list-1

Article cited in:

http://jmg.bmj.com/content/47/8/513.full.html\#related-urls

Email alerting Receive free email alerts when new articles cite this article. Sign up in service the box at the top right corner of the online article.

Topic
Collections

Articles on similar topics can be found in the following collections

Molecular genetics (1143 articles)

Notes

To request permissions go to:

http://group.bmj.com/group/rights-licensing/permissions

To order reprints go to:

http://journals.bmj.com/cgi/reprintform

To subscribe to BMJ go to:

http://group.bmj.com/subscribe/ 